\title{
Minat Generasi Z Menggunakan Kembali Transaksi Mobile Payment: Pendekatan Model UTAUT 2
}

\section{Generation Z Interest Continuence Use Intention Mobile Payment Transactions: UTAUT 2 Model Approach}

\author{
Yestias Maharani* \\ Akuntansi, Fakultas Bisnis Ekonomi, Universitas Islam Indonesia, Indonesia \\ Diterima: 05 Agustus 2021 Direview: 05 Agustus 2021 Disetujui: 05 September 2021
}

*Coresponding Email: 113120407@uii.ac.id

\begin{abstract}
Abstrak
Generasi z merupakan generasi yang hidup dalam era teknologi sehingga mereka sudah terbiasa menggunakan teknologi dalam kehidupan sehari-hari termasuk mobile payment. Penelitian ini dilakukan untuk melihat hubungan antara variabel yeng terdapat dalam UTAUT 2 ditambah variabel kepuasan dengan keinginan untuk menggunakan kembali transaksi mobile payment. Responden yang dilibatkan merupakan generasi z sebanyak 146 orang, generasi z merupakan generasi yang tumbuh di tengah kemajuan teknologi sehingga mereka sudah sangat terbiasa menggunakan teknologi dan sistem informasi termasuk diantaranya mobile payment. Variabel ekspektasi kinerja, ekspektasi usaha, pengaruh sosial, kondisi fasilitas, motivasi hedonis, nilai perolehan tidak berpengaruh signifikan terhadap niat generasi z menggunakan kembali transaksi mobile payment. Sedangkan kebiasaan dan kepercayaan berpengaruh signifikan terhadap niat generasi z menggunakan kembali transaksi mobile payment. Hal ini dikarenakan generasi z merupakan generasi milenial yang sudah terbiasa menggunakan teknologi seperti transksi mobile payment, dan merasa percaya bahwa transaksi mobile payment yang mereka lakukan bisa menjaga pivasi atas data yang mereka miliki.
\end{abstract}

Kata Kunci: UTAUT 2; Kepercayaan; Generasi Z; Mobile Payment.

\section{Abstract}

$Z$ generation is a generation that lives in the era of technology so that they are used to using technology in their daily lives, including mobile payments. This study was conducted to see the relationship between the variables contained in UTAUT 2 and additional variable trust with the desire to continuance use intention mobile payments. The UTAUT 2 variables used in this study are performance expectations, effort expectations, social influences, facility conditions, hedonic motivation, price value, habits and the additional variable used in this study is trust. Respondents involved in this study were Generation $Z$ as many as 146 people, Generation $Z$ is a generation that grew up in the midst of technological advances so that they are very accustomed to using technology and information systems including mobile payments. The variables of performance expectation, effort expectation, social influence, facility condition, hedonic motivation, price value have no significant effect on the creation of generation z to continuance use intention mobile payments transactions. Meanwhile, habits and beliefs have a significant influence on making $z$ intentions to reuse cellular payment transactions. This is because generation $z$ is a millennial generation who is used to using technology such as mobile payment transactions, and feels confident that their mobile payment transactions can maintain privacy for their data.

Keywords: UTAUT 2; Trust; Z Generation; Mobile Payment.

How to Cite: Maharani, Y. (2021). Minat Generasi Z Menggunakan Kembali Transaksi Mobile Payment: Pendekatan Model UTAUT 2. Jurnal Akuntansi dan Bisnis : Jurnal Program Studi Akuntansi. 4 (1): 140-154 


\section{PENDAHULUAN}

Semakin meningkatnya keinginan masyarakat untuk menggunakan uang elektronik sebagai alat pembayaran, menyebabkan bermunculan beberapa jenis uang elektronik baik yang dikeluarkan oleh perusahaan perbankan maupun perusahaan server. Misalnya EMoney dari Bank Mandiri, Tap Cash dari Bank Negara Indonesia, Brizzi dari Bank rakyat Indonesia dan juga beberapa merk uang elektronik lainnya, adapun uang elektronik non bank berbasis server yang terlisensi oleh Bank Indonesia antara lain Go-pay, OVO, Doku Wallet, Dana, Shopeepay, dan lain sebagainya. Transaksi jual beli berbasis server dianggap sebagai salah satu faktor yang menyebabkan penggunaan uang elektronik mengalami peningkatan yang cukup pesat, beberapa perusahaan server yang menyediakan transaksi jual beli dan pembayaran elektronik antara lain GOJEK, Shopee, Lazada, OVO dan lain sebagainya. Selain dimudahkan dengan pembelian tanpa harus datang ke toko, pelanggan juga dimanjakan dengan berbagai diskon dan juga cashback yang dapat menghemat pengeluaran. Kemudahan dalam mengatur pengeluaran dan meminimalisir risiko uang hilang dianggap juga sebagai manfaat pengguna uang elektronik.

Permasalahan yang terjadi, uang elektronik hanya sering dipergunakan oleh masyarakat yang tinggal di kota besar dan berpenghasilan cukup, Penelitian yang dilakukan (Adiyanti \& Arsita, 2015) ketika seseorang memiliki pendapatan yang tinggi dan cukup, maka seseorang tersebut memiliki minat untuk membeli suatu produk juga cukup tinggi. Keinginan mereka untuk melakukan transaksi dengan cara yang cepat dan efisien menjadikan transaksi digital sebagai salah satu jalan keluar untuk dapat membeli barang atau produk yang mereka inginkan. Selain itu sarana dan prasarana untuk melakukan akses pembayaran dengan uang elektronik dipandang masih minim. Menurut (Sembiring \& Malinda, 2016) masih minimnya akses perbankan hingga ke pelosok dan belum meratanya jaringan internet yang stabil menjadi kendala utama uang elektronik belum bisa diterima dengan baik oleh seluruh masyarakat Indonesia dan hanya terpusat di kotakota besar saja.

Mobile payment merupakan aplikasi dipergunakan sebagai alat transaki pengganti uang tunai yang terpasang dalam aplikasi smartphone, adapun berbagai macam mobile payment yang saat ini tersedia, diantaranya Gopay, OVO, Shopeepay dan lain sebagainya. Menurut (Ghezzi et al., 2010) mobile payment merupakan proses yang membutuhkan satu tahap transaksi dengan media yang menggunakan perangkat telepon seluler ( smartphone ). Sedangkan menurut (Slade et al., 2013) mobile payment merupakan alat pembayaran non tunai yang menghubungkan pelanggan, pedagang dan juga pihak bank. Mobile payment alat yang digunakan untuk melakukan pembayaran secara non tunai yang saat ini sedang mengalami perkembangan, hal ini ditunjukkan semakin banyaknya minat pengguna layanan untuk menggunakan mobile payment dibandingkan dengan transaksi tunai. Ketika masyarakat ingin melakukan belanja secara online, mayoritas marketplace tersebut menawarkan transaksi pembayaran dengan menggunakan mobile payment. Selain itu dengan metode pembayaran mobile payment, pengguna tidak perlu repot untuk melakukan pembayaran melalui tatap muka secara langsung, namun yang perlu diketahui layanan mobile payment hanya bisa dilakukan dengan menggunakan jaringan internet dan juga smartphone.

Menurut (Bhattacherjee, 2001) dalam teori ECM (Expectation Confirmation Model) setelah pengguna teknologi merasakan manfaat lebih dari teknologi yang digunakan, akan membuat pengguna teknologi memiliki niat untuk melanjutkan kembali penggunaan teknologi tersebut. Penelitian yang dilakukan oleh (Tam et al., 2018) melakukan modifikasi dengan menggabungkan variabel niat untuk menggunakan kembali dengan 
UTAUT2, hal ini dilakukan untuk mendapatkan pemahaman yang baik mengenai niat untuk menggunakan kembali aplikasi seluler .The unified theory of acceptance and use of technology (UTAUT) awalnya memiliki empat kontruksi yaitu ekspektasi kinerja (performance expectation), ekspektasi usaha ( effort expectation), pengaruh social (social influence), dan kondisi fasilitas (facilitating condition). Model ini umumnya digunakan untuk menjelaskan faktor-faktor yang mempengaruhi penggunaan sebuah teknologi informasi (Singh et al., 2017). Kemudian motivasi hedonis (hedonic motivation), nilai perolehan (price value), dan kebiasaan (habbit) mulai dikembangkan oleh Venkatesh et al., (2012) yang disebut dengan UTAUT 2. Oliveira et al., (2016) dalam penelitianyang dilakukan mengenai minat masyarakat untuk memberikan rekomendasi penggunaan aplikasi mobile payment dengan pendekatan UTAUT 2, penyebaran inovasi atas teknologi dan juga persepsi keamanan sebuah teknologi, pengguna teknologi beranggapan bahwa teknologi yang menggunakan data pribadi yang sensitive dan kemampuan teknologi dalam menjaga keamanan transaksi, merupakan hal yang cukup penting bagi pengguna dalam menggunakan teknologi mobile payment.

Penelitian yang dilakukan oleh (Susanto et al., 2016)mengenai faktor yang mendasari niat melanjutkan penggunaan layanan perbankan dengan menggunakan smartphone menguji faktor yang mendasari pengguna mobile banking tetap menggunakan layanan tersebut, adapun variable yang digunakan dalam penelitian ini yaitu niat untuk melanjutkan penggunaan, kepercayaan, persepsi keamanan dan privasi, dan efektifitas diri. Hasil dari penelitian ini yaitu efektifitas diri, kepuasan pengguna berpengaruh terhadap niat pengguna untuk tetap menggunakan aplikasi mobile banking sedangkan kepercayaan tidak berpengaruh signifikan terhadap niat pengguna untuk tetap menggunakan layanan mobile banking. Penelitian yang dilakukan oleh (Purnamasari, 2017) dari responden sebanyak 1002 orang di wilayah Jabodetabek sebanyak 38,42\% pengguna uang elektronik berusia 20 sampai dengan 25 tahun, 24,75\% berusia 26 sampai dengan 29 dan sekitar 20,76\% berusia 30 sampai dengan 36 tahun, hal ini menunjukkan bahwa minat pengguna uang elektronik didominasi oleh kalangan usia 20 sampai dengan 36 Tahun, selama ini penelitian yang dilakukan masih memiliki objek penelitian yang relative umum yaitu seluruh kalangan yang menggunakan transaksi mobile payment, Pentingnya untuk melihat persepsi dari sisi generasi z dikarenakan generasi z merupakan generasi yang sudah terbiasa menggunakan teknologi dalam kehidupan mereka sehari hari termasuk dalam melakukan transaksi.

Berdasarkan data yang dihasilkan, mayoritas pengguna mobile payment adalah masyarakat usia 20 sampai 25 Tahun, Daerah Istimewa Yogyakarta sebagai kota pelajar memiliki potensi sebagai pengguna uang elektronik sebagai pembayaran transaksi, Dalam penelitian ini mencoba untuk mengkombinasikan penelitian yang dilakukan oleh Tam et al., (2018) dan Susanto et al., (2016) dengan melakukan uji model UTAUT 2 dengan menambahkan variable kepercayaan (trust) dan niat untuk menggunakan kembali ( Continuance Use Intention ). Penelitian ini menggunakan sampel mahasiswa Diploma III Akuntansi yang termasuk dalam kategori generasi $\mathrm{Z}$, generasi Z merupakan generasi yang lahir pada tahun 1995 sampai 2010 yang mampu mengaplikasikan teknologi berbasis internet dalam satu waktu secara bersamaan (Wijoyo et al., 2020). Adapun transaksi Lesscash yang dimaksud dalam penelitian ini yaitu transaksi pembayaran dengan menggunakan mobile payment seperti OVO, Gopay, Shopeepay. Masih minimnya penelitian yang menggunakan objek generasi $\mathrm{z}$ dalam menggunakan transaksi dengan mobile payment dengan menggunakan model penelitian UTAUT 2 ditambah dengan kepercayaan. 
Menutur (Venkatesh et al., 2012), motivasi hedonis muncul dikarenakan pengguna teknologi merasa senang untuk menggunakan teknologi tersebut. Nilai perolehan ( price value ) timbul karena pengguna teknologi mengeluarkan biaya untuk dapat memperoleh teknologi yang dibutuhkan sedangkan kebiasaan (habbit) timbul karena pengguna teknologi merasa terbiasa menggunakan transaksi atau kegiatan dengan menggunakan teknologi yang ada. Ekspektasi kinerja merupakan sejauh mana pandangan seseorang bahwa sistem dapat membantu meningkatkan kinerja orang tersebut (Chiu et al., 2008). Menurut Tam et al., (2018) jika pengguna aplikasi merasakan bahwa penggunaan aplikasi sangat bermanfaat, dia akan mendapatkan kepuasan yang lebih dari ekspektasi awalnya. Disisi lain, ekspektasi kinerja dalam hal pemberian manfaat, telah terbukti menjadi alat untuk memprediksi manfaat yang dirasakan oleh pengguna teknologi, selain itu pengguna teknologi aplikasi seluler akan terus menggunakan aplikasi tersebut apabila mereka yakin bahwa aplikasi tersebut memberikan hasil yang positif.

H1 : Ekspektasi kinerja memiliki pengaruh positif terhadap niat generasi z menggunakan kembali transaksi mobile payment

Ketika pengguna percaya bahwa aplikasi seluler meberikan manfaat tetapi pada saat yang bersamaan mungkin pengguna aplikasi juga berpendapat bahwa aplikasi seluler sulit untuk digunakan, sehingga manfaat yang nantinya diperoleh akan diimbangi dengan usaha yang harus dikeluarkan untuk bisa menggunakan aplikasi seluler tersebut dengan baik (Tam et al., 2018). Menurut Venkatesh (2012) semakin kompleks suatu inovasi dalam sebuah teknologi maka akan semakin rendah keinginan pengguna tekhnologi dalam menggunakan kembali teknologi tersebut. Berdasarkan hal tersebut, ekspektasi usaha akan memberikan dampak kepada minat pengguna untuk menggunakan kembali teknologi tersebut, semakin sedikit upaya yang harus dilakukan untuk menggunakan aplikasi mobile payment maka semakin besar keinginan pengguna untuk menggunakan kembali aplikasi mobile payment tersebut.(Tam et al., 2018).

H2 : Ekspektasi usaha memiliki pengaruh positif terhadap niat generasi z untuk menggunakan kembali transaksi mobile payment

Menurut Zhou (2014) pengaruh social memiliki pengaruh yang signifikan terhadap keiginan untuk menggunakan kembali sebuah teknologi dalam hal ini mobile payment. Hasil ini sejalan dengan penelitian yang dilakukan oleh Tam et al, (2018) semakin besar pengaruh social dari penggunaan mobile payment maka semakin besar pula niat untuk menggunakan kembali aplikasi tersebut.

H3 : Pengaruh social memiliki pengaruh positif terhadap niat generasi $\mathrm{z}$ untuk menggunakan kembali transaksi mobile payment

Penelitian yang dilakukan oleh (Rosnidah et al., 2018) pengguna yang memiliki akses untuk menggunakan fasilitas yang mendukung lebih cenderung memiliki niat yang besar untuk menggunakan sebuah teknologi. Kondisi fasilitas adalah sebuah konstruksi yang mencerminkan persepsi individu mengenai pengendalian atas perilakunya (Venkatesh et al., 2012). Berdasarkan hal tersebut maka dapat disimpulkan bahwa semakin banyak kondisi fasilitas yang mendukung terkait penggunaan mobile payment maka semakin besar juga niat pengguna untuk menggunakan kembali mobile payment.

H4 : Kondisi fasilitas memiliki pengaruh positif terhadap niat generasi $\mathrm{z}$ untuk menggunakan kembali transaksi mobile payment

Motivasi hedonis merupakan sebuah motivasi yang timbul karena kesenangan yang diperoleh dari mengadopsi sebuah teknologi (Venkatesh et al., 2012). Pada zaman modern seperti saat ini setiap kegiatan telah didominasi dengan penggunaan teknologi salah satunya mobile payment, hal ini menyebabkan sebagian besar masyarakat telah familiar 
dengan penggunaan mobile payment bagi kehidupan mereka termasuk generasi z. Generasi z termasuk kelompok masyarakat yang sangat menggemari teknologi termasuk mobile payment, apabila sebuah teknologi membawa kebahagiaan bagi pengguna dan pengguna sangat senang saat menggunakannya itu akan mempengaruhi niat perilaku mereka. Mobile payment merupakan salah satu aplikasi yang akan menyenangkan bagi pengguna karena merupakan sebuah bentuk baru dari transaksi keuangan. Menurut (Moorthy, et al., 2019) ketika individu menerima kebahagian dari penggunaan mobile payment, mereka cenderung akan terus menggunakan aplikasi tersebut dalam kehidupan mereka sehari hari. Berdasarkan latar belakang tersebut, maka dapat disimpulkan bahwa motivasi hedonis akan mempengaruhi niat untuk menggunakan kembali aplikasi mobile payment.

H5 : Motivasi Hedonis memiliki pengaruh positif terhadap niat generasi $\mathrm{z}$ untuk menggunakan kembali transaksi mobile payment.

Menurut Venkatesh et al., (2012) komponen biaya dan harga mungkin memiliki pengaruh signifikan terhadap penggunaan teknologi, pada pasar aplikasi seluler, pengguna aplikasi seluler tidak hanya diberikan berbagai pilihan aplikasi seluler yang memberikan berbagai macam fungsi tetapi kebanyakan dari aplikasi seluler tersebut tidak berbayar, tetapi beberapa pengguna memilih untuk menggunakan aplikasi seluler yang berbayar dengan fungsi yang sama tetapi memiliki kualitas yang jauh lebih baik (Hsu et al., 2015). Berdasarkan latar belakang tersebut, maka dapat disimppulkan bahwa harga perolehan atas pengguna aplikasi mobile payment akan mempengaruhi niat pengguna untuk menggunakan kembali aplikasi mobile payment.

H6 : Nilai harga memiliki pengaruh positif terhadap niat generasi z untuk menggunakan kembali transaksi mobile payment

Pengguna Teknologi yang memiliki pengalaman dalam menggunakan teknologi informasi biasanya akan membentuk kebiasaan yang kemudian akan mempengaruhinya untuk terus menggunakan teknologi informasi tersebut (Amoroso et al., 2017). Maka dapat disimpulkan bahwa kebiasaan menggunakan aplikasi seluler akan mendorong niat untuk terus menggunakan aplikasi seluler tersebut dalam hal ini mobile payment.

H7 : Kebiasaan memiliki pengaruh positif terhadap niat generasi z untuk menggunakan kembali transaksi mobile payment

Menurut Mayer et al., (1995) kepercayaan merupakan sebuah kesanggupan seseorang untuk menjadi penanggung atas tindakan yang dilakukan orang lain, dengan harapan orang tersebut melakukan tindakan yang berguna bagi orang yang menaruh kepercayaan tersebut, terlepas kemampuan penangung untuk memantau pihak yang ditanggung. Kepercayaan dibangun dari tiga faktor pembangun yang melekat pada kepercayaan yaitu pertama kemampuan atau kompetensi pemegang amanat, merupakan serangkaian keterampilan dan kompetensi dalam melaksanakan tujuan seseorang; kedua yaitu kebajikan merupakan niat baik kepada orang lain dan yang terakhir yaitu integritas yang merupakan norma tetap dalam mempercayai orang lain. Kesimpulannya niat kepercayaan dapat bervariasi karena bergantung pada hubungan, pengalaman, fase perkembangan dan indikasi dalam sebuah kondisi yang ada. Menurut Zhou (2014) kepercayaan sebagai kunci utama yang menentukan pelanggan untuk tetap menggunakan aplikasi mobile banking. Alalwan et al., (2017) mengemukakan bahwa kepercayaan memiliki pengaruh besar pada niat pengguna layanan aplikasi mobile banking untuk menggunakan kembali layanan tersebut, karena pengguna merasa aman dan percaya bahwa bank mampu menyimpan informasi probadi milik pengguna dengan benar. Tingkat kepuasan ini dipengaruhi oleh kepercayaan yang merupakan dampak dari penerimaan 
manfaat atas sebuah teknologi (Susanto et al., 2016; Liébana-Cabanillas et al., 2013; Venkatesh et al., 2011)

H8 : Kepercayaan memiliki pengaruh positif terhadap niat generasi z untuk menggunakan kembali transaksi mobile payment.

\section{METODE PENELITIAN}

Dalam melakukan pengujian model penelitian, pemilihan sampel menggunakan metode purposive sampling dengan kriteria yaitu pengguna aplikasi mobile payment dalam melakukan transaksi pembayaran dan berumur kurang dari 25 tahun. Responden tersebut digunakan untuk melakukan penelitian minat generasi $\mathrm{Z}$ menggunakan transaksi mobile payment dengan menggunakan model pendekatan UTAUT 2 dan menggabungkannya dengan variable kepercayaan (trust) dan niat untuk menggunakan kembali, sesuai dengan penelitian yang dilakukan oleh Tam et al., (2018) dan Susanto et al., (2016). Penelitian ini merupakan penelitian kuantitatif, menggunakan kuisioner yang disebarkan melalui googleform kepada responden yang termasuk kategori yaitu generasi $\mathrm{z}$ yang memanfaatkan aplikasi mobile payment. Sebanyak 148 responden telah berpartisipasi, tetapi 2 orang responden tidak melakukan pengisian data secara lengkap, sehingga untuk pengujian data hanya menggunakan 146 responden. Penelitian ini memakai skala likert 1 sampai dengan skala 6, skala ini memberikan gambaran terkait tingkat kesetujuan responden terhadap masing-masing pertanyaan yang diajukan. Adapun jenis pertanyaan yang digunakan yaitu, untuk niat melanjutkan penggunaan mobile payment menggunakan 3 jenis pertanyaan, jenis pertanyaan ini diambil dari Bhattacherjee, (2001). Sementara variable ekspektasi kinerja menggunakan 4 jenis pertanyaan, ekspektasi usaha menggunakan 4 jenis pertanyaan, pengaruh sosial menggunakan 3 jenis pertanyaan, kondisi fasilitas menggunakan 3 item pertanyaan, motivasi hedonis menggunakan 3 jenis pertanyaan, Nilai Harga menggunakan 3 jenis pertanyaan, kebiasaan menggunakan 4 jenis pertanyaan. Item ekspektasi kinerja, ekspektasi usaha, pengaruh social, kondisi fasilitas, motivasi hedonis, nilai harga, dan kebiasaan diadopsi dari penelitian Tam et al., (2018). Dan untuk variable kepercayaan diadopsi dari penelitian Susanto et al., (2016) dengan menggunakan 3 item pertanyaan. Tabel 1. Jenis Pertanyaan Pengukuran Variabel

\begin{tabular}{|c|c|c|}
\hline Variabel & & Pengukuran \\
\hline \multirow{3}{*}{$\begin{array}{l}\text { Niat } \\
\text { melanjutkan } \\
\text { penggunaan } \\
\text { mobile payment } \\
\text { (continuance } \\
\text { intention) }\end{array}$} & NM 1 & $\begin{array}{l}\text { Saya ingin melanjutkan penggunaan mobile payment dan tidak bermaksud } \\
\text { menghentikan penggunaan mobile payment }\end{array}$ \\
\hline & NM 2 & $\begin{array}{l}\text { Saya ingin menggunakan mobile payment dalam melakukan pembayaran } \\
\text { dibandingkan dengan menggunakan cara lain }\end{array}$ \\
\hline & NM 3 & $\begin{array}{l}\text { Saya ingin terus menggunakan mobile payment secara terus menerus seperti } \\
\text { yang saat ini saya lakukan }\end{array}$ \\
\hline \multirow{4}{*}{$\begin{array}{l}\text { Ekspektasi } \\
\text { Kinerja }\end{array}$} & EK1 & Mobile payment berguna untuk menjalankan pekerjaan saya \\
\hline & EK2 & Mobile payment memungkinkan saya melakukan pekerjaan dengan lebih cept \\
\hline & EK 3 & $\begin{array}{l}\text { Melakukan pembayaran dengan mobile payment akan meningkatkan } \\
\text { produktivitas saya }\end{array}$ \\
\hline & EK 4 & $\begin{array}{l}\text { Melakukan pembayaran dengan mobile payment akan meningkatkan kinerja } \\
\text { saya }\end{array}$ \\
\hline \multirow{4}{*}{$\begin{array}{l}\text { Ekspektasi } \\
\text { Usaha }\end{array}$} & EU1 & $\begin{array}{l}\text { Pembayaran dengan menggunakan mobile payment mudah dimengerti dan } \\
\text { memberikan informasi yang jelas }\end{array}$ \\
\hline & EU2 & $\begin{array}{l}\text { Menggunakan mobile payment sangat mudah dan saya lebih cepat mahir dalam } \\
\text { penggunaannya }\end{array}$ \\
\hline & EU3 & Mobile payment sangat mudah untuk digunakan sebagai alat pembayaran \\
\hline & EU4 & Mobile payment sangat mudah untuk dioperasikan \\
\hline \multirow{2}{*}{$\begin{array}{l}\text { Pengaruh } \\
\text { Sosial }\end{array}$} & PS1 & $\begin{array}{l}\text { Lingkungan memberi pengaruh kepada saya untuk menggunakan mobile } \\
\text { payment }\end{array}$ \\
\hline & PS2 & Keluarga saya mendorong saya untuk menggunakan mobile payment \\
\hline
\end{tabular}


Yestias Maharani. Minat Generasi Z Menggunakan Kembali Transaksi Mobile Payment : Pendekatan Model UTAUT 2

\begin{tabular}{|c|c|c|}
\hline Variabel & & Pengukuran \\
\hline \multirow{4}{*}{$\begin{array}{l}\text { Kondisi } \\
\text { Fasilitas }\end{array}$} & PS3 & $\begin{array}{l}\text { Saya menggunakan mobile payment karena pengaruh orang yang pendapatnya } \\
\text { saya hargai }\end{array}$ \\
\hline & KF1 & $\begin{array}{l}\text { Sumber daya yang saya miliki mendukung saya untuk menggunakan mobile } \\
\text { payment }\end{array}$ \\
\hline & KF2 & $\begin{array}{l}\text { Pengetahuan yang saya memiliki, mendukung saya untuk menggunakan mobile } \\
\text { payment }\end{array}$ \\
\hline & KF3 & $\begin{array}{l}\text { Perangkat yang saya miliki mendukung saya untuk menggunakan mobile } \\
\text { payment }\end{array}$ \\
\hline \multirow{3}{*}{$\begin{array}{l}\text { Motivasi } \\
\text { Hedonis }\end{array}$} & MH1 & Aplikasi mobile payment menyenangkan \\
\hline & MH2 & Aplikasi mobile payment tidak susah dioperasikan dan mudah dipahami \\
\hline & MH3 & Mobile payment merupakan aplikasi yang sangat menghibur \\
\hline \multirow{3}{*}{ Nilai Harga } & NH1 & Aplikasi Mobile payment dapat dijangkau \\
\hline & NH2 & Mobile payment adalah memberikan harga terbaik \\
\hline & NH3 & $\begin{array}{l}\text { Mobile payment memberikan nilai yang baik untuk digunakan pada kondisi } \\
\text { seperti saat ini }\end{array}$ \\
\hline \multirow{4}{*}{ Kebiasaan } & KB1 & Aplikasi mobile payment sudah biasa saya gunakan dalam kehidupan sehari hari \\
\hline & KB2 & Saya ketagihan untuk menggunakan aplikasi mobile payment \\
\hline & KB3 & Saya ingin terus menggunakan aplikasi mobile payment \\
\hline & KB 4 & Menggunakan aplikasi mobile payment merupakan kegiatan normal bagi saya \\
\hline \multirow{3}{*}{ Kepercayaan } & KP1 & $\begin{array}{l}\text { Mobile payment memberikan kepercayaan kepada diri saya untuk } \\
\text { penggunaannya }\end{array}$ \\
\hline & KP2 & Mobile payment yang saya aplikasikan, sesuai dengan kepentingan saya \\
\hline & KP3 & Mobile payment yang saya aplikasikan memuat informasi yang jujur dan akurat \\
\hline
\end{tabular}

\section{Teknik Analisis Data} Uji Asumsi Klasik

Pengujian asumsi klasik dilakukan untuk menilai terkait metode OLS yang digunakan dapat memberikan nilai prediksi yang blue, adapun pengujian asumsi klasik pada penelitian ini antara lain uji multikolinieritas, uji heteroskedastisitas, dan uji autolinieritas. Uji multikonieritas merupakan suatu masalah dimanan terdapat hubungan antara variabel independent, pengujian heteroskedastisitas merupakan suatu permasalahan dimana varian yang terdapat dalam variabel gangguan yang tidak tetap sehingga penguji tidak lagi memiliki varian yang minimum tetapi masihberada dalam pengujian yang sama dan tidk bias, sedangkan uji autokorelaso merupakan hubungan antara variabel eror yang satu disandingkan dengan variabel eror yang lain. (Widarjono, 2009)

\section{Analisis Regresi}

Pengujian hipotesis yang dilakukan pada penelitian ini yaitu dengan pengujian model regresi berganda. Model regresi berganda yaitu sebuah pengujian dengan menggunakan metode statistik yang dipakai untuk mengetahui pola hubungan antar variabel. Adapun bentuk regresi pada penelitian ini adalah sebagai berikut :

$$
N M=\beta_{0}+\beta_{1} E K+\beta_{2} E U+\beta_{3} P S+\beta_{4} K F+\beta_{5} M H+\beta_{6} N H+\beta_{7} K B+\beta_{8} K P+e
$$

\section{HASIL DAN PEMBAHASAN}

Dalam penyusunan penelitian ini, data yang dihasilkan berasal dari remaja yang termasuk dalam golongan generasi $\mathrm{Z}$, melalui penyebaran kuesioner sebanyak 146 responden. Terdiri dari 113 orang berjenis kelamin perempuan dan 33 orang berjenis kelamin laki-laki, rentan usia para responden yaitu sebanyak 77 orang berusia kurang dari 20 tahun, 68 orang berusia antara 20 sampai dengan 25 tahun, dan satu orang responden berusia lebih dari 25 tahun. Jenis layanan yang digunakan oleh responden yaitu 26 orang responden menggunakan mobile banking, 43 responden menggunakan aplikasi Ovo, 31 
orang responden menggunakan aplikasi Go Pay, 25 orang responden menggunakan shoopepay, 8 orang responden menggunakan aplikasi Danaku, dan 13 orang responden menggunakan aplikasi lainnya.

\section{Pengujian Multikolinieritas}

\section{Tabel 2}

Uji Multikolineraitas

\begin{tabular}{|c|c|c|c|c|c|c|c|c|}
\hline & EK & EU & PS & KF & MH & NH & KB & KP \\
\hline EK & 1.00 & 0.65 & 0.42 & 0.72 & 0.67 & 0.49 & 0.57 & 0.49 \\
\hline EU & 0.65 & 1.00 & 0.23 & 0.68 & 0.72 & 0.59 & 0.58 & 0.60 \\
\hline PS & 0.42 & 0.23 & 1.00 & 0.34 & 0.32 & 0.26 & 0.31 & 0.19 \\
\hline KF & 0.72 & 0.68 & 0.34 & 1.00 & 0.65 & 0.54 & 0.56 & 0.55 \\
\hline MH & 0.67 & 0.72 & 0.32 & 0.65 & 1.00 & 0.65 & 0.60 & 0.59 \\
\hline NH & 0.49 & 0.59 & 0.26 & 0.54 & 0.65 & 1.00 & 0.54 & 0.57 \\
\hline KB & 0.57 & 0.58 & 0.31 & 0.56 & 0.60 & 0.54 & 1.00 & 0.64 \\
\hline KP & 0.49 & 0.60 & 0.19 & 0.55 & 0.59 & 0.57 & 0.64 & 1.00 \\
\hline
\end{tabular}

Hasil pengujian multikolinieritas yang telah dilakukan maka dapat disimpulkan bahwa seluruh variabel memiliki korelasi 0,85 sehingga terbebas dari masalah multikolinearitas.

\section{Pengujian Heteoskedastisitas}

Tabel 3. Pengujian Heteroskedastisitas

\begin{tabular}{cccc}
\hline \hline F Statistik & 1.770097 & Prb F(8,137) & 0.0881 \\
R Squared & 13.67731 & Prb. ChiSquare(8) & 0.0906 \\
Nilai Skala SS & 13.34519 & Prb. ChiSquare(8) & 0.1005 \\
\hline \hline
\end{tabular}

Berdasarkan pengujian heteroskedastisitas yang dilakukan dengan menggunakan uji white maka dapat disimpulkan bahwa nilai obs*R-Squared sebesar 13,67731 dan nilai prob.Chi-Square sebesar 0,0906 dimana lebi besar dari alpha 0,05 sehingga tidak terdapat masalah heteroskedastisitas.

\section{Pengujian Autokorelasi}

Tabel 4. Uji Autokorelasi

Breusch-Godfrey Serial Correlation LM Test:

\begin{tabular}{cccc}
\hline \hline Nilai F Statistik & 1.439498 & Nilai Prb F (2,135) & 0.2407 \\
Obs*R-squared & 3.048568 & Nilai Prb ChiSquare(2) & 0.2178 \\
\hline \hline
\end{tabular}

Hasil uji autokorelasi menunjukkan bahwa nilai obs*RSquared sebesar 3,048568 dan nilai prb.ChiSquare sebesar 0,2178 dimana lebi besar dari alpha 0,05 sehingga tidak terdapat masalah autokorelasi. Berdasarkan uji asumsi klasik maka dapat disimpulkan bahwa estimasi model pengaruh valid untuk dilakukan pengujian statistika.

\section{Analisis Regresi}

Tabel 5. Hasil Estimasi Regresi 
Yestias Maharani. Minat Generasi Z Menggunakan Kembali Transaksi Mobile Payment : Pendekatan Model UTAUT 2

\begin{tabular}{|c|c|c|c|c|c|}
\hline \multicolumn{6}{|c|}{ Independent Variabel : NM } \\
\hline Variabel & $\begin{array}{c}\text { Nilai } \\
\text { Koefisien }\end{array}$ & $\begin{array}{l}\text { Standar } \\
\text { Error }\end{array}$ & $\begin{array}{c}\text { Nilai t } \\
\text { Statistik }\end{array}$ & Nilai Prob Dua Sisi & Nilai Prob Satu Sisi \\
\hline $\mathrm{C}$ & 0,182787 & 0,341741 & 0,534871 & 0,593600 & 0,2968 \\
\hline EK & 0,109874 & 0,090454 & 1,214694 & 0,226600 & 0,1133 \\
\hline EU & $-0,099241$ & 0,087188 & $-1,138247$ & 0,257000 & 0,1285 \\
\hline PS & 0,037770 & 0,036121 & 1,045667 & 0,297600 & 0,1488 \\
\hline $\mathrm{KF}$ & $-0,057371$ & 0,085251 & $-0,672963$ & 0,502100 & 0,25105 \\
\hline MH & 0,066841 & 0,082560 & 0,809603 & 0,419600 & 0,2098 \\
\hline $\mathrm{NH}$ & $-0,040128$ & 0,065388 & $-0,613691$ & 0,540400 & 0,2702 \\
\hline $\mathrm{KB}$ & 0,240466 & 0,069920 & 3,439167 & 0,000800 & $0,0004^{* * *}$ \\
\hline KP & 0,703892 & 0,081571 & 8,629230 & 0,000000 & $0,0000^{* * *}$ \\
\hline \multicolumn{6}{|c|}{ Nilai RSquare 0,661380 Nilai Fstatistic 33,44795 } \\
\hline
\end{tabular}

Tabel uji kelayakan diatas memperlihatkan, nilai F statistic 33,4, tingkat probabilitas 0,00 dimana nilai $\alpha=5$ persen, maka dapat diambil kesimpulan bahwa variable independen berpengaruh terhadap variable dependen karena tingkat probabilitas atas pengujian ini $<5$ persen. Hasil pengujian regresi menunjukkan hasil nilai R-square sebesar $66,14 \%$. Hal ini berarti variasi variable dependen mampu dijelaskan oleh variasi variable independen sebanyak 66,14\% dan sebanyak 33,86 dijelaskan oleh variable lain diluar model.

Pada hasil pengujian pengaruh ekspektasi kinerja terhadap niat untuk menggunakan kembali transaksi mobile payment, diperoleh hasil pengujian t sebesar 1,21 dengan nilai probabilitas satu sisi sebesar 0,11 . Nilai probabilitas yang diperoleh dalam penelitian ini $>\alpha=10$, uji ini menunjukkan hasil yang tidak signifikan. Berkenaan dengan hasil atas pengujian yang dilakukan tersebut, ekspektasi kinerja tidak berpengaruh signifikan terhadap niat generasi z untuk menggunakan kembali transaksi mobile payment, generasi $\mathrm{z}$ memiliki anggapan bahwa peningkatan dalam penyelesaian kinerja tidak memiliki pengaruh dalam menggunakan mobile payment dalam melakukan transaksi. Menurut survey yang dilakukan oleh (Warta Ekonomi, 2020) 75\% generasi muda saat ini menggunakan transaksi mobile payment dikarenakan tertarik dengan promo-promo yang diberikan. Generasi z memiliki anggapan bahwa penggunaan mobile payment tidak untuk meningkatkan kinerja mereka tetapi hanya diperuntukan sebagai sarana untuk memenuhi kebutuhan sehari-hari .

Hasil uji yang dilakukan pada penelitian ini bertentangan dengan penelitian yang dilakukan oleh Tam et al., (2018), ekspektasi kinerja memiliki pengaruh signifikan terhadap niat generasi $\mathrm{z}$ untuk menggunakan kembali mobile payment, hal ini dikarenakan responden penelitian yang dilakukan oleh Tam et al., (2018) adalah masyarakat umum yang menggunakan mobile payment dalam melakukan transaksi, sedangkan responden pada penelitian ini adalah generasi z yang tergolong berusia kurang dari 25 tahun yang berstatus sebagai mahasiswa atau pelajar, dimana mereka masih belum memiliki pekerjaan yang menjadikan mobile payment sebagai salah satu pendukung kinerja dari pekerjaan mereka. Hasil penelitian ini sejalan dengan penelitian yang dilakukan oleh (Megadewandanu et al., 2016) mobile payment masih dalam tahap pengenalan produk untuk dapat digunakan dalam kehidupan sehari-hari, dimana sebagian besar penggunanya merupakan pemula. Generasi Z merupakan generasi dengan usia dibawah 25 tahun, mayoritas dari generasi $\mathrm{Z}$ belum mengaplikasikan dengan optimal mobile payment sebagai upaya untuk meningkatkan kinerja hasil ini selaras dengan penelitian yang dilakukan oleh (Im et al., 2011). 
Pada hasil pengaruh ekspektasi usaha terhadap niat untuk menggunakan kembali transaksi mobile payment, diperoleh nilai t statistik sebesar -1,13 dengan nilai probabilitas satu sisi sebesar 0,13. Dengan kata lain nilai probabilitas yang diperoleh dalam penelitian ini $>\alpha=10$ dengan kata lain, hasil yang diperoleh menunjukkan tidak signifikan. Maka dapat disimpulkan bahwa ekspektasi usaha tidak berpengaruh signifikan terharap niat generasi z untuk menggunakan kembali mobile banking. Hal ini dikarenakan, generasi z adalah generasi yang sudah sangat mahir dalam menerapkan teknologi, sehingga mereka tidak memerlukan usaha yang besar untuk bisa menggunakan mobile payment, sehingga dapat disimpulkan bahwa usaha bukan menjadi alasan generasi z menggunakan kembali layanan mobile payment. Hasil uji ini tidak sesuai dengan penelitian yang dilakukan oleh Venkatesh (2012), terdapat pengaruh antara ekspektasi usaha dengan minat untuk menggunakan transaksi mobile payment, perbedaan ini mungkin dikarenakan responden yang digunakan untuk penelitian ini adalah generasi z yaitu generasi yang lahir di zaman teknologi sehingga mereka lebih mudah dalam menggunakan sebuah teknologi dibandingkan generasi-generasi sebelumya. Hasil penelitian ini sejalan dengan penelitian yang dilakukan oleh Moorthy et al., (2019), Slade et al. (2015), Morosan \& Defranco (2016), Yeh \& Tseng (2017).

Pengujian variabel pengaruh sosial terhadap variabel niat untuk menggunakan kembali transaksi mobile payment yaitu tidak berpengaruh signifikan dimana nilai $\mathrm{t}$ sebesar 1,05 dan probabilitas uji satu sisi sebesar 0,15. Hasil ini sejalan dengan penelitian yang dilakukan oleh Tam et al., (2018) dan (Moorthy, et al., 2019), pengaruh sosial tidak memiliki pengaruh yang signifikan terhadap niat generasi z untuk menggunakan kembali mobile payment dikarenakan mereka tumbuh di era teknologi (Muda et al., 2015), sehingga lingkungan sekitar baik keluarga maupun pertemanan tidak mempengaruhi mereka untuk menggunakan kembali layanan mobile payment. Generasi z menghabiskan sebagian waktunya di depan komputer, handphone dan juga berbagai teknologi lainnya, sehingga ketika mereka menggunakan salah satu aplikasi dari teknologi tersebut seperti mobile payment, mereka tidak membutuhkan pengaruh dari lingkungan sosial terlebih dahulu. Hasil penelitian ini juga sejalan dengan Wang \& Yi (2012), Miltgen, et al., (2013), Jambulingam (2013), Masa'deh, et al., (2016) dan Prasarry, et al., (2015).

Hasil pengujian atas kondisi fasilitas terhadap niat generasi $\mathrm{z}$ untuk menggunakan kembali transaksi mobile payment tidak berpengaruh signifikan dimana nilai t statistik sebesar -0,67 dan probabilitas lebih besar dari 0,1 yaitu sebesar 0,25. Generasi z merupakan generasi muda yang sangat dekat dengan teknologi, kemampuan menggunakan teknologi yang lebih mudah dtangkap oleh generasi z menjadikan mereka lebih mudah menggunakan teknologi tanpa harus melakukan pembelajaran secara formal terlebih dahulu. Ketergantungan terhadap kondisi fasilitas dalam menggunakan mobile payment lebih sering dialami oleh wanita lanjut usia pada tahap awal penggunaan teknologi, hal ini dikarenakan wanita usia lanjut belum begitu memahami dengan baik bagaimana menggunakan teknologi di era saat ini, sehingga mereka membutuhkan fasilitas pendukung yang bisa memberikan kemudahan bagi mereka untuk menggunakan mobile payment ( Venkatesh et al., 2012). Pengujian ini sejalan dengan penelitian yang dilakukan oleh Tam et al., (2018) kondisi fasilitas bukan merupakan faktor yang penting untuk menggunakan layanan mobile payment, namun demikian kondisi fasilitas dapat mempengaruhi penyedia layanan mobile payment untuk menyusun strategi dalam mengatasi tekanan sosial dan memberikan kemudahan pemasangan bagi calon pengguna mobile payment seperti kelompok masyarakat yang tidak terbiasa menggunakan 
teknologi. Hasil penelitian ini juga sejalan dengan penelitian yang dilakukan oleh (ArenasG et al., 2015), (Megadewandanu et al., 2016).

Hasil pengujian atas variable motivasi hedonis terhadap niat untuk menggunakan kembali transaksi mobile payment yaitu tidak signifikan, dimana nilai t statistik sebesar 0,81 dan nilai probabilitas lebih dari 0,1 yaitu sebesar 0,2 . Model pembayaran dengan menggunakan teknologi seperti mobile payment terbilang masih cukup baru bagi masyarakat di negara berkembang seperti Indonesia, sehingga sangat diperlukan adanya sebuah fasilitas yang menjadikan pengguna merasa senang ketika menggunakan layanan mobile payment. Bagi generasi $\mathrm{z}$, layanan mobile payment masih dianggap sebuah aplikasi yang tidak cukup penting sekali untuk menunjang kehidupan sehari-hari, selain itu fasilitas yang disediakan oleh layanan mobile payment tidak cukup membantu mereka menyelesaikan pekerjaan mereka sehari-hari. Menurut (Tam et al., 2018) motivasi hedonis terkait dengan aplikasi seluler seperti mobile payment terbukti tidak relevan dengan niat untuk menggunakan kembali mobile payment tersebut, perusahaan aplikasi mobile payment sebaiknya bisa memunculkan sebuah fiture pada layanan mobile payment yang bisa menarik pengguna terutama generasi z untuk memiliki loyalitas yang dalam menggunakan layanan tersebut, dan secara terus menerus dapat melakukan pembaharuan sesuai dengan kebutuhan mereka sebagai generasi milenial.

Hasil pengujian atas nilai harga terhadap niat untuk menggunakan kembali transaksi mobile payment yaitu tidak berpengaruh signifikan, dimana nilai t sebesar -0,61 dan nilai probabilitas sebesar 0,27. Menurut (Tam et al., 2018) nilai harga dianggap bukan menjadi alasan utama pengguna mobile payment untuk menggunakan kembali layanan mobile payment, penyedia layanan aplikasi mobile payment sebaiknya menyadari bahwa pengguna terutama generasi $\mathrm{z}$ cenderung lebih memilih produk yang gratis dan terjangkau (Hsu \& Lin, 2015). Walaupun generasi $\mathrm{z}$ adalah generasi yang berkembang ditengah kemajuan teknologi, mereka cenderung lebih menyukai aplikasi yang tidak mengeluarkan biaya yang mahal dan terjangkau dengan keuangan yang mereka miliki, mengingat mayoritas responden berusia kurang dari 25 tahun dan masih berstatus pelajar, sehingga untuk mengeluarkan biaya pada penggunaan aplikasi mobile payment menjadi pertimbangan yang berat bagi mereka. Penelitian ini sejalan dengan (Tam et al., 2018) dan (Hsu \& Lin, 2015)

Hasil pengujian atas variabel kebiasaan terhadap niat untuk menggunakan kembali transaksi mobile paymenr (continous intention) berpengaruh signifikan dimana nilai $\mathrm{t}$ sebesar 3,43 dan probabilitas satu sisi sebesar 0,04. Variabel Kebiasaan, mempunyai koefisien positif sebesar 0,24 . Keinginan untuk melanjutkan penggunaan mobile payment sebesar 0,24 satuan. Generasi z sudah sangat terbiasa dengan penggunaan teknologi, menurut (Bencsik et al., 2016) teknologi dan informasi merupakan hal yang biasa bagi generasi $\mathrm{z}$, karena mereka terlahir di lingkungan yang sudah mengenal dan menerima dengan baik penerapan teknologi. Penerapan teknologi yang baik menjadikan generasi z juga menganggap bahwa penggunaan mobile payment merupakan sebuah kebiasaan bagi mereka ketika melakukan transaksi dan menjadi alasan bagi mereka untuk menggunakan kembali transaksi mobile payment di kemudian hari. Menurut (Megadewandanu et al., 2016) pengguna mobile payment mulai terbiasa dengan metode pembayaran mobile payment karena dirasa cukup mudah, dapat digunakan dimana saja, kapan saja dan dengan perangkat yang memang mereka miliki. Menurut (Tam et al., 2018) kebiasaan merupakan salah satu faktor penting yang mendorong niat berkelanjutan pengguna mobile payment, hal ini menunjukkan bahwa perusahaan dan pengembang aplikasi seluler seharusnya membuat atau memperbaharui aplikasi mobile payment agar mudah untuk digunakan, dengan kata lain penggunaan aplikasi mobile payment seharusnya tidak 
membutuhkan upaya dan waktu yang lama untuk mempelajari penggunaanya dan memungkinkan mereka untuk dapat menggunakannya lebih cepat dan pada akhirnya akan menjadi kebiasaan (Amoroso et al., 2017). Penelitian ini sejalan dengan penelitian yang dilakukan oleh (Bhattacherjee, 2001) (Gaitan et al., 2015).

Hasil pengujian atas variabel kepercayaan terhadap niat untuk menggunakan kembali transaksi mobile payment berpengaruh signifikan dimana nilai t statistik sebesar 8,63 dan probabilitas lebih kecil dari 0,1 yaitu sebesar 0,00. Variabel Kepercayaan, mempunyai koefisien positif sebesar 0,70. Tingkat keamanan yang dirasakan oleh pengguna ketika menggunakan aplikasi mobile payment sebesar 1 satuan akan menyebabkan kenaikan Keinginan untuk melanjutkan penggunaan mobile payment sebesar 0,70 satuan. Kepercayaan merupakan kunci utama bagi seorang pelanggan untuk menggunakan kembali sebuah produk begitu juga dengan mobile payment, pengguna mobile payment beranggapan bahwa ketika layanan mobile payment menjamin kerahasiaan data milik pengguna, pengguna merasa akan percaya dan akan terus menggunakan layanan mobile payment. Dengan adanya tingkat keamanan yang baik dalam melakukan transaksi dan juga informasi yang akurat dan tepat waktu menjadikan alasan pengguna mobile payment merasa percaya untuk menggunakan mobile payment. Begitu juga generasi $\mathrm{z}$ yang merasa bahwa transaksi mobile payment memberikan tingkat keamanan yang baik dan informasi yang akurat sehingga mereka merasa nyaman dan percaya untuk terus menggunakan mobile payment sebagai media pembayaran. Penelitian ini sejalan dengan penelitian yang dilakukan oleh Alalwan et al., (2015), Lu et al., (2011).

Penelitian ini diharapkan dapat memberikan konstribusi pengembangan baik dalam dunia praktis maupun teoritis. Penelitian ini melakukan pengembangan model UTAUT 2 dengan menambahkan variabel kepercayaan, dengan responden penelitian generasi z. Generasi z merupakan generasi yang hidup di era teknologi sehingga mereka terbiasa mengaplikasikan teknologi dalam kehidupan sehari-hari termasuk dalam penggunaan mobile payment. Menurut generasi z, latarbelakang mereka menggunakan aplikasi mobile payment, karena mereka terbiasa untuk menggunakan aplikasi tersebut, dan percaya atas aplikasi mobile payment yang mereka gunakan, hal ini tentunya menjadi masukan bagi para penyedia layanan mobile payment untuk terus memperbaharui aplikasi yang mereka hasilkan, agar sesuai dengan kebutuhan para pengguna aplikasi mobile payment termasuk generasi z. Generasi z berharap, para penyedia layanan mobile payment, dapat menambah fitur-fitur yang sesuai dengan kebutuhan dan memberikan kemudahan bagi generasi z.

Faktor kepercayaan juga menjadi alasan bagi generasi $\mathrm{z}$ untuk menggunakan kembali aplikasi mobile payment, hal ini menjadi perhatian khusus bagi penyedia mobile payment untuk tetap memberikan keamanan bagi para pengguna layanan tersebut. Ketika pengguna merasa aman terhadap suatu aplikasi, bisa dipastikan pengguna tersebut akan menggunakan kembali aplikasi yang memberikan jaminan keamanan atas transaksi yang dilakukan (Alalwan et al., 2015). Jaminan atas keamanan yang baik pada saat melakukan transaksi dan informasi yang akurat dan tepat waktu menjadi alasan bagi generasi z untuk menggunakan kembali layanan mobile payment. Generasi z masih menganggap bahwa aplikasi mobile payment yang ada saat ini tidak memberikan kemudahan bagi pekerjaan mereka sehari-hari, kurangnya sinkronisasi yang dilakukan penyedia layanan mobile payment dengan berbagai aplikasi yang dibutuhkan generasi $\mathrm{z}$ menjadikan generasi $\mathrm{z}$ merasa kurang terbantu dengan layanan yang diberikan oleh aplikasi mobile payment.Hal ini dapat menjadi pertimbangan bagi penyedia layanan untuk bisa menambah fitur yang terdapat di aplikasi mobile payment dan disesuaikan dengan kebutuhan generasi z saat ini. 


\section{SIMPULAN}

Penelitian ini bertujuan untuk melihat hubungan antara variabel yang terdapat dalam UTAUT 2 ditambah variable kepercayaan dengan keinginan untuk menggunakan kembali (continuance intention) mobile payment. Adapun variabel UTAUT 2 yang digunakan dalam penelitian ini yaitu ekspektasi kinerja (performance expectation), ekspektasi usaha ( effort expectation), pengaruh social (social influence), kondisi fasilitas (facilitating condition), motivasi hedonis (hedonic motivation), nilai perolehan (price value), dan kebiasaan (habbit) dan variabel tambahan yang digunakan dalam penelitian ini adalah kepercayaan (trust). Responden yang dilibatkan pada penelitian ini merupakan generasi z sebanyak 146 orang, generasi z merupakan kelompok masyarakat yang tumbuh ditengah kemajuan teknologi sehingga mereka sudah sangat terbiasa menggunakan teknologi dan sistem informasi termasuk diantaranya mobile payment. Variabel ekspektasi kinerja, ekspektasi usaha, pengaruh sosial, kondisi fasilitas, motivasi hedonis, nilai perolehan tidak memeiliki pengaruh signifikan terhadap niat generasi z menggunakan kembali transaksi mobile payment. Sedangkan kebiasaan dan kepercayaan berpengaruh signifikan terhadap niat generasi z menggunakan kembali transaksi mobile payment. Hal ini dikarenakan generasi $\mathrm{z}$ menrupakan generasi milenial yang sudah terbiasa menggunakan teknologi seperti transksi mobile payment, dan merasa percaya bahwa transaksi mobile payment yang mereka lakukan bisa menjaga pivasi atas data yang mereka miliki.

Hasil penelitian yang dilakukan, memberikan saran bagi penyedia aplikasi mobile payment untuk memperbaharui layanan yang diberikan pada aplikasi mobile payment dan disesuaikan dengan kebutuhan generasi z, mengingat generasi z merupakan generasi yang sangat dekat dan familiar dengan teknologi, sehingga bisa menjadi pangsa pasar yang baik bagi penyedia layanan mobile payment. Misalnya saja menjalin kerjasama dengan platform pada segmen hobi dan hiburan, seperti video on demand, streaming, music on demand dan lain sebagainya dimana fitur-fitur tersebut merupakan fitur yang saat ini sedang berkembang di kalangan generasi z. Penambahan fitur dianggap cukup penting bagi generasi z untuk menggunakan kembali mobile payment, hal ini akan lebih memudahkan generasi z untuk memenuhi kebutuhan hobi, hiburan, kebutuhan sehari-harai hanya dalam genggaman tangan.

\section{DAFTAR PUSTAKA}

Adiyanti, A. I., (2015). Pengaruh Pendapatan, Manfaat, Kemudahan Penggunaan, Daya Tarik, Promosi, Dan Kepercayaan terhadap Minat Menggunakan Layanan E-Money. Jurnal Ilmiah Mahasiswa FEB, p. 3.

Alalwan, A. A. et al., (2015). Consumer adoption of Internet banking in Jordan: Examining the role of hedonic motivation, habit, self-efficacy and trust. Journal of Financial Services Marketing, pp. 145-157.

Amoroso, D. L. \& Chen, Y., (2017). Constructs Affecting Continuance Intention in Consumers With Mobile Financial Apps: A Dual Factor Approach. Journal of Information Technology Management, pp. 2-24.

Arenas-G, J., Peral-P, B. \& Ramo'n, M. A., (2015). Elderly and Internet Banking: An Application of UTAUT2. Journal of Internet Banking and Commerce, pp. 1-23.

Bencsik, A., Juhász, T. \& Horváth-Csikós's, G., (2016). Y and Z Generations at Workplaces. Journal of Competitiveness, 90-106.

Bhattacherjee, A., (2001). Understanding Information Systems Continuance: An Expectation-Confirmation Model. pp. 351-370.

Chiu, C.-M. \& Wang, E. T., (2008). Understanding Web-based learning continuance intention: The role of subjective task value. Elsevier, pp. 194-201.

Gaitan, J. A., Peral-Peral, B. \& Jeronimo, M. A., (2015). Elderly and Internet Banking: An Application of UTAUT2. Journal of Internet Banking and Commerce. 1-24.

Ghezzi, A., Renga, F., Balocco, R. \& Pescetto, P., (2010). Mobile payment applications: offer state ofthe art in the Italian market. Emerald, 3-22.

Ghozali, I., (2018). Aplikasi Analisis Multivariate Dengan Program SPSS 25. Semarang: Badan Penerbit Universitas Diponegoro. 
Hsu, C. L. \& Lin, C. -C., (2015). What drives purchase intention for paid mobile apps? - An expectation confirmation model with perceived value. Electronic Commerce Research and Applications. 46-57.

Im, I., Hong, S. \& Kang , M. S., (2011). An International Comparison of 99 Technology Adoption: Testing The UTAUT Model. Information and Management. 1-8.

Jambulingam, M., (2013). Behavioural intention to adopt mobile technology among tertiary students. World Applied Sciences Journal, 22, 1262-1271.

Liébana-Cabanillas, F., Munoz-Leiva, F. \& Rejon-Guardila, F., (2013). The determinants of satisfaction with e-banking. Industrial Management and Data System, 113, 750-767.

Lu, Y., Yang, S., Chau, P. Y. K. \& Cao, Y., (2011). Dynamics Between The Trust Transfer Process and Intention to Use Mobile Payment Services : A Cross- environment Perspective. Information \& Management. 393-403.

Masa'deh, R., Tarhini, A., Mohammed, A. B. \& Maqableh, M., (2016). Modeling factors affecting student's usage behavior of E-learning systems in Lebanon. 11, 299-312.

Mayer, R. C., Davis, J. H. \& Schoorman, F. D., (1995). Ab Integrative Model Of Organizational Trust. Academy of Management Review, 20, 709-734.

Megadewandanu, S., Pranowo, P. \& Suyoto, S., (2016). Exploring mobile wallet adoption in Indonesia using UTAUT2: An approach from consumer perspective. Yogyakarta, IEEE, 1-6.

Miltgen, C. L., Popovic, A. \& Oliveira, T., (2013). eterminants of end-user acceptance of biometrics: Integrating the "Big 3" of technology acceptance with privacy context. Decision Support Systems, 56, 103-114.

Moorthy, K. et al., (2019). What drives the adoption of mobile payment? A Malaysian perspective. Wiley, 1-16.

Morosan, C. \& Defranco, A. L., (2016). It's about time: Revisiting UTAUT2 to examine consumers' intentions to use NFC mobile payments in hotels. International Journal of Hospitality Management, 53, 17-29.

Muda, M., Mohd, R. \& Hassan, S., (2015). Online purchase behavior of generation Y in Malaysia. Procedia Economics and Finance, 292-298.

Oliveira, T., Thomas, M., Baptista, G. \& Campos, F., (2016). Mobile payment: Understanding the determinants of customer adoption and intention to recommend the technology. Elsevier, 404-414.

Oliver, R. L., (1980). A Cognitive Model of the Antecedents and Consequences of Satisfaction Decisions. Journal of Marketing Research, 460-469.

Prasarry, Y. V., Astuti, E. S. \& Suyadi , I., (2015). Factors affecting the adoption of mobile commerce (a study on SMEs in Malang). European Journal of Business and Management, 7, 30-35.

Priyanto, D., (2017). Panduan Praktis Olah Data Menggunakan SPSS. Yogyakarta: Andi.

Purnamasari, D., (2017). 50,90\% Masyarakat Khawatirkan Penggunaan Data e-Money. [Online] Available at: https://tirto.id/5090-masyarakat-khawatirkan-penggunaan-data-e-monev-cy41 [Accessed 2012 2020].

Rosnidah, I., Muna, A., Musyaffi, A. M. \& SIregar, N. F., (2018). Critical Factor of Mobile Payment Acceptance in Millenial Generation. Atlantis Press, 123-127.

Sembiring, M., (2016). Mewujudkan Less Cash Society. [Online] Available at:https://www.kompasiana.com/malindasembiring/58371260349773560bb38950/mewujudkan-lesscash-society [Accessed 10112020$]$.

Singh, M. \& Matsui, Y., (2017). How Long Tail and Trust Affect Online Shopping Behavior: An Extension to UTAUT2 Framework. Pasific Asia Journal of The Association for Information System, 1-24.

Slade, E. L., Williams, M. D. \& Dwivedi, Y. K., (2013). Mobile payment adoption: Classification and review of the extant literature. Emerald, 167.

Susanto, A., Chang, Y. \& Ha, Y., (2016). Determinants of continuance intention to use the smartphone banking services. Emerald Insight, 508-525.

Tam, C., Santos, D. \& Oliveira, T., (2018). Exploring the influential factors of continuance intention to use mobile apps: extending the expectation confirmation model. Information Systems Frontiers, 243-257.

Teddie, C. \& Yu, F., 2007. Mixed methods sampling: A typology with examples. Journal of Mixed Methods Research 1,(1), 77-100.

Venkatesh, V., Thong, J. \& Xu, X., (2012). Consumer Acceptance and Use of Information Technology: Extending the Unified Theory of Acceptance and Use of Technology1. Mis Quarterly, 157-178.

Wang, L. \& Yi, Y., (2012). The impact of use context on mobile pay- ment acceptance: An empirical study in China. Advances in Com- puter Science and Education, 293-299.

JWarta Ekonomi, (2020). Ada Apa dengan Generasi Milenial Pengguna E-Payment?. [Online] Available at: https://www.wartaekonomi.co.id/read269532/ada-apa-dengan-generasi-milenial-penggunae-pavment [Accessed 2812 20].

Widarjono, A., (2009). Ekonometrika : Pengantar dan Aplikasinya. Ketiga ed. Yogyakarta: Ekonisia.

Wijoyo, H., Cahyono, Y. \& Indrawan , I., (2020). GENERASI Z \& REVOLUSI INDUSTRI 4.0. Purwokerto: CV. Pena Persada. 
Yestias Maharani. Minat Generasi Z Menggunakan Kembali Transaksi Mobile Payment : Pendekatan Model UTAUT 2

Yeh, M. L. \& Tseng, Y. L., (2017). he college students' behavior intention of using mobile payments in Taiwan: An exploratory research. nternational Journal of Management and Applied Sci- ence, 3, 89-93.

Zhou, T., (2014). Understanding the determinants of mobile payment continuance usage. Emerald Insight, $936-948$. 